\title{
NAD+ and NAD+ analogues in horse liver alcohol dehydrogenase : relationship between reactivity and conformation simulated with molecular mechanics
}

Citation for published version (APA):

Beijer, N. A., Buck, H. M., Sluyterman, L. A. A. E., \& Meijer, E. M. (1990). NAD+ and NAD+ analogues in horse liver alcohol dehydrogenase : relationship between reactivity and conformation simulated with molecular mechanics. Biochimica et Biophysica Acta, Protein Structure and Molecular Enzymology, 1039(2), 227-233. https://doi.org/10.1016/0167-4838(90)90190-Q

DOI:

10.1016/0167-4838(90)90190-Q

Document status and date:

Published: 01/01/1990

Document Version:

Publisher's PDF, also known as Version of Record (includes final page, issue and volume numbers)

Please check the document version of this publication:

- A submitted manuscript is the version of the article upon submission and before peer-review. There can be important differences between the submitted version and the official published version of record. People interested in the research are advised to contact the author for the final version of the publication, or visit the $\mathrm{DOI}$ to the publisher's website.

- The final author version and the galley proof are versions of the publication after peer review.

- The final published version features the final layout of the paper including the volume, issue and page numbers.

Link to publication

\footnotetext{
General rights

- You may freely distribute the URL identifying the publication in the public portal. follow below link for the End User Agreement:

www.tue.nl/taverne

\section{Take down policy}

If you believe that this document breaches copyright please contact us at:

openaccess@tue.nl

providing details and we will investigate your claim.
}

Copyright and moral rights for the publications made accessible in the public portal are retained by the authors and/or other copyright owners and it is a condition of accessing publications that users recognise and abide by the legal requirements associated with these rights.

- Users may download and print one copy of any publication from the public portal for the purpose of private study or research.

- You may not further distribute the material or use it for any profit-making activity or commercial gain

If the publication is distributed under the terms of Article $25 \mathrm{fa}$ of the Dutch Copyright Act, indicated by the "Taverne" license above, please 


\title{
$\mathrm{NAD}^{+}$and $\mathrm{NAD}^{+}$analogues in horse liver alcohol dehydrogenase. Relationship between reactivity and conformation simulated with molecular mechanics
}

\author{
Nicoline A. Beijer, Henk M. Buck, Lamoraal A.AE. Sluyterman and Emmo M. Meijer \\ Department of Organic Chemistry, Eindhoven University of Technology, Eindhoven (The Netherlands)
}

(Received 10 October 1989)

Key words: Molecular modelling; Coenzyme-enzyme interaction; NAD ${ }^{+} ; \mathrm{NAD}^{+}$analog; AMBER; Enzyme kinetics

In the present study we show that the enzymatic activity of the coenzyme nicotinamide adenine dinucleotide $\left(\mathrm{NAD}^{+}\right)$ and its analogues $\left(\mathrm{C}(\mathrm{O}) \mathrm{NH}_{2}\right.$ replaced by $\mathrm{C}(\mathrm{S}) \mathrm{NH}_{2}, \mathrm{C}(\mathrm{O}) \mathrm{CH}_{3}, \mathrm{C}(\mathrm{O}) \mathrm{H}$ and $\left.\mathrm{CN}\right)$ with horse liver alcohol dehydrogenase (LADH) (alcohol:NAD ${ }^{+}$oxidoreductase, EC 1.1.1.1) can be rationalized by their conformation in the active site determined with molecular mechanics (AMBER, assisted model building with energy refinement). In order to establish the relation between the hydride transfer rate and the conformation of the $\mathrm{NAD}^{+}$and its analogues, kinetic experiments with the poor substrate isopropanol were carried out. It appears that the enzymatic activity can be readily explained by the geometry of the pyridinium ring, in particular the magnitude of the 'out-of-plane' rotation of the carboxamide side chain (or analogues). The latter is nicely illustrated in the case of 3-cyanopyridine adenine dinucleotide which lacks any 'out-of-plane' rotation and concomitantly exhibits no significant enzymatic activity.

\section{Introduction}

More insight into the mechanism of dehydrogenase action can be gained by examining the effects of replacing the coenzyme $\mathrm{NAD}^{+}$by $\mathrm{NAD}^{+}$analogues. Of special interest are those which are modified in the reactive part, the nicotinamide moiety. Kinetic data with such analogues have been published on various dehydrogenases [1-11], but no systematic explanation has so far been provided for their reactivities. In the present paper a qualitative explanation using molecular mechanics calculations is reported.

Horse liver alcohol dehydrogenase (LADH) (alcohol:NAD ${ }^{+}$oxidoreductase, EC 1.1.1.1) has been

\footnotetext{
Abbreviations: $\mathrm{LADH}$, horse liver alcohol dehydrogenase; $\mathrm{Me}_{2} \mathrm{SO}$, dimethyl sulfoxide; $\mathrm{NAD}^{+} / \mathrm{NADH}$, nicotinamide adenine dinucleotide and its reduced form; $\mathrm{ac}^{3} \mathrm{PdAD}{ }^{+} / \mathrm{ac}^{3} \mathrm{PdADH}$, 3-acetylpyridine adenine dinucleotide and its reduced form; $\mathrm{sNAD}^{+} / \mathrm{sNADH}$, thionicotinamide adenine dinucleotide and its reduced form; $\mathrm{fPdAD}^{+} / \mathrm{fPdADH}, 3-$ formylpyridine adenine dinucleotide and its

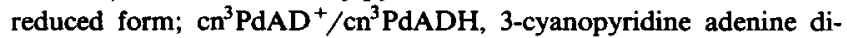
nucleotide and its reduced form; UV/VIS, ultraviolet/visible light; AMBER, assisted model building with energy refinement; MNDO, minor neglect of differential overlap program.
}

Correspondence: N.A. Beijer, Department of Organic Chemistry, Eindhoven University of Technology, P.O. Box 513, 5600 MB Eindhoven, The Netherlands. chosen for the present study because much is known about this enzyme, particularly the X-ray structure of a ternary complex with $\mathrm{Me}_{2} \mathrm{SO}$ [12]. Furthermore, the enzyme shows a broad specificity and is therefore of great potential utility in preparative applications.

The chemical step in the enzymatic conversion is the hydride ion transfer from the alcohol to the coenzyme or vice versa. If $\mathrm{NAD}^{+}$is used as coenzyme and ethanol as substrate, the rate-limiting step is the dissociation of the coenzyme from the enzyme [13]. On the other hand, when the poor substrate isopropanol is used, it has been shown by presteady-state measurements that the hydride transfer is rate limiting [13]. In order to relate the hydride transfer rate to the conformation of the $\mathrm{NAD}^{+}$ analogues in the active site, kinetic experiments with isopropanol were therefore carried out in this study. It is self-evident, that, for comparing various analogues, the intrinsic reactivity of each, i.e., the non-enzymatic reaction rate with dithionite, must also be taken into account.

Referring to the required structural data, the position of the pyridinium moiety relative to the substrate should first be studied. There is, however, a second structural factor that may be involved: the 'out-of-plane' rotation $\phi$ of the side chain of the pyridinium ring (Fig. 1a).

The concept of the 'out-of-plane' rotation has been introduced by Donkersloot and Buck [14]. According to 
<smiles></smiles>
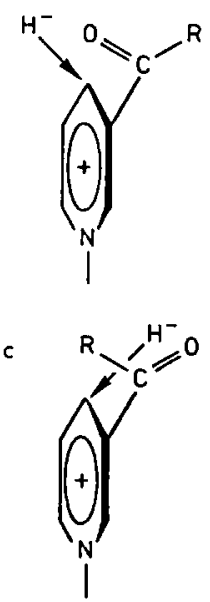

Fig. 1. (a) 'Out-of-plane' rotation of the carboxamide side chain, $\phi=0$ : The $\mathrm{CO}$ group is situated in the plane of the pyridinium ring (in the orientation drawn), (b) and (c) represent the entry of the hydride ion in the direction of the carbonyl group. (b) A specificity; (c) B specificity.

their quantum chemical calculations, the enthalpy of the transition state of the hydride transfer is lowered when the carboxamide group is rotated out of the pyridinium plane, the carbonyl group pointing towards the face of the plane to which the hydride ion is transferred.

The calculations were experimentally verified with model compounds having the $\mathrm{CO}$ group forced out of the pyridinium plane $[15,16]$. The rate of transfer to the face of the plane where the carbonyl group protrudes proved to exceed the rate at the opposite face to such an extent as to produce complete stereospecificity in the absence of any enzyme: A specificity in the case of Fig. 1b, B specificity in Fig. 1c.

In dehydrogenases the $A$ and $B$ specificity is determined by the spatial relationship of substrate and pyridinium moiety (A specificity in LADH, B specificity in GAPDH). The 'out-of-plane' rotation will therefore affect, not the specificity, but the rate of hydride transfer; for effective enzyme action the side chain carbonyl group should therefore be directed more or less towards the substrate. Such is indeed the case in LADH $\left(\phi=30^{\circ},[12]\right)$ and in GAPDH $\left(\phi=22^{\circ},[17]\right)$, as observed by $\mathrm{X}$-ray analysis.

For the present study we used the analogues thionicotinamide adenine dinucleotide $\left(\mathrm{sNAD}^{+}\right)$, 3acetylpyridine adenine dinucleotide $\left(\mathrm{ac}^{3} \mathrm{PdAD}^{+}\right)$, 3-formylpyridine adenine dinucleotide $\left(\mathrm{fPdAD}^{+}\right)$and $3-$ cyanopyridine adenine dinucleotide $\left(\mathrm{cn}^{3} \mathrm{PdAD}^{+}\right)$carrying the pyridine side chains $\mathrm{C}(\mathrm{S}) \mathrm{NH}_{2}, \mathrm{C}(\mathrm{O}) \mathrm{CH}_{3}, \mathrm{C}(\mathrm{O}) \mathrm{H}$ and $\mathrm{CN}$, respectively. Unfortunately, for the corresponding LADH-coenzyme complexes no X-ray data are available. We therefore resorted to molecular mechanics calculation to assess the geometry of the analogues and its interactions with the enzyme. This procedure proved to be reliable for $\mathrm{NAD}^{+}$as the calculational results were found to correlate closely with the available $X$-ray data $[18,19]$.

It will be shown in the present paper that the enzymatic activity of the $\mathrm{NAD}^{+}$and its analogues can be rationalized in terms of geometric features, taking into account the intrinsic reactivities.

\section{Materials and Methods}

\section{Enzyme kinetics}

Horse liver alcohol dehydrogenase (EC 1.1.1.1) was purchased from Boehringer-Mannheim. NAD ${ }^{+}$, $\mathrm{ac}^{3} \mathrm{PdAD}^{+}, \mathrm{sNAD}^{+}$and $\mathrm{fPdAD}^{+}$were obtained from Sigma Chemical Company. The substrates ethanol and isopropanol, and the phosphates of the $0.047 \mathrm{M}$ phosphate buffer used (with $0.25 \mathrm{mM}$ EDTA, $\mathrm{pH}=7.0$, $\Gamma=0.1$ ) were from Merck. The purity of the alcohols was checked using gas chromatography. Enzyme solutions were centrifuged prior to use. Kinetic experiments were carried out at $22^{\circ} \mathrm{C}$ on a Hitachi 150-20 UV/VIS spectrophotometer equipped with a data processor. The steady-state initial rates of $\mathrm{NAD}^{+}, \mathrm{sNAD}^{+}, \mathrm{fPdAD}^{+}$ and $\mathrm{ac}^{3} \mathrm{PdAD}^{+}$, respectively, were measured following the formation of the reduced pyridine nucleotide at an appropriate wavelength $\left(\mathrm{NAD}^{+} / \mathrm{NADH}, \lambda=340 \mathrm{~nm}\right.$, $\epsilon=6220 \mathrm{M}^{-1} \cdot \mathrm{cm}^{-1} ; \mathrm{sNAD}{ }^{+} / \mathrm{sNADH}, \lambda=396 \mathrm{~nm}$, $\epsilon=10000 \mathrm{M}^{-1} \cdot \mathrm{cm}^{-1} ; \mathrm{ac}^{3} \mathrm{PdAD}^{+} / \mathrm{ac}^{3} \mathrm{PdADH}, \quad \lambda=$ $363 \mathrm{~nm}, \epsilon=9000 \mathrm{M}^{-1} \cdot \mathrm{cm}^{-1} ; \mathrm{fPdAD}^{+} / \mathrm{fPdADH}, \lambda=$ $\left.358 \mathrm{~nm}, \epsilon=7800 \mathrm{M}^{-1} \cdot \mathrm{cm}^{-1}[8,20,21]\right)$. The concentration range of the coenzyme was $10-100 \mu \mathrm{M}$ (with the exception of $\mathrm{fPdAD}^{+}$, which varied from $100-1000$ $\mu \mathrm{M})$. The substrate concentration ranged from 2-19 $\mathrm{mM}$.

Kinetic parameters in the initial-rate equation [13]:

$1 / V=e / k_{\mathrm{cat}}\left(1+K_{\mathrm{a}} /[\mathrm{A}]+K_{\mathrm{b}} /[\mathrm{B}]+K_{\mathrm{c}} /[\mathrm{A}][\mathrm{B}]\right)$

were obtained from the primary and secondary plots of the initial-rate data. In Eqn. 1, $e$ is the concentration of enzyme active centres (twice the molar concentration); $A$ and $B$ represent coenzyme and substrate, respectively; $K_{\mathrm{a}}, K_{\mathrm{b}}$ and $K_{\mathrm{c}}$ denote the kinetic coefficients.

At saturating ethanol concentration the measured $k_{\text {cat }}$ values (data not shown) are in accordance with literature data $[6,7,9-11,22,23]$.

\section{Procedure for calculational studies}

Energy calculations and total energy minimization energies were performed with the AMBER molecular 
mechanics package (version 3.0) [24] on a VAX 11/785 computer. We used AMBER to minimize a total energy function consisting of separate terms covering bondstretching (I), -bending (II) and torsional angles (III), as well as Van der Waals, electrostatic (IV) and hydrogen bond $(\mathrm{V})$ interactions (AMBER energies, Eqn. 2).

$$
\begin{aligned}
& E_{\text {total }}=\underset{\text { bonds }}{\sum} K_{R}\left(R-R_{\text {eq }}\right)^{2}+\underset{\text { angles }}{\sum} K_{\theta}\left(\theta-\theta_{\text {eq }}\right)^{2} \\
& +\sum_{\text {dihedrals }} \frac{V_{n}}{2}[1+\cos (n \phi-\gamma)]+\underset{\text { III }}{\sum}\left(\frac{A_{i j}}{R_{i j}^{12}}-\frac{B_{i j}}{R_{i j}^{6}}+\frac{q_{i} q_{j}}{\varepsilon R_{i j}}\right) \\
& +\underset{\text { Hbonds }}{\Sigma}\left(\frac{C_{i j}}{R_{i j}^{12}}-\frac{D_{i j}}{R_{i j}^{10}}\right)
\end{aligned}
$$

The procedure is identical to the method described in our previous papers $[18,19]$. The active site of LADH was constructed from X-ray crystallographic data of a ternary complex of $\mathrm{NAD}^{+} / \mathrm{LADH} / \mathrm{Me}_{2} \mathrm{SO}$ reported by Eklund and co-workers [12] $(0.29 \mathrm{~nm}$ resolution, crystallographic $R$ factor of 0.22 ) which was readily retrievable from the Brookhaven Protein Database. The three-dimensional structures of the $\mathrm{NAD}^{+}$analogues were derived directly from the $\mathrm{X}$-ray $\mathrm{NAD}^{+}$geometry using an interactive computer graphics program (ChemX, January 1989 update, copyright Chemical Design Oxford, Oxford). During the energy minimization the amino acids and the zinc ion were fixed at their initial positions. The cysteine residues of the core of amino acids (Cys-46 and Cys-174) were introduced as negatively charged residues as described in our earlier paper [18]. All minimizations were performed until the RMS gradient value of the energy was less than $4.18 \mathrm{~kJ} \cdot \mathrm{nm}^{-1}$ $\left(1.0 \mathrm{kcal} \cdot \mathrm{nm}^{-1}\right)$, using the distance-dependent dielectric constant and treating all $\mathrm{CH}, \mathrm{CH}_{2}$ and $\mathrm{CH}_{3}$ groups as united atoms.

Atomic charges were calculated using the MNDO semi-empirical molecular orbital method. Most harmonic force constants were obtained from the literature or extrapolated from available data $[25,26]$. For the calculation of the 'out-of-plane' rotation appropriate values for the rotation barriers $V_{\mathrm{n}}$ had to be inserted in Eqn. 2 . However, for the pyridinium compounds no experimental values were found in literature, and moreover quantum chemical calculations did not provide sufficiently reliable results $[14,27]$. The experimental values of the closely related benzene derivatives, benzamide, benzaldehyde and benzophenone $[28,29]$ were therefore taken. These values may be assumed to be a close approximation to those of the pyridinium compounds $\mathrm{NAD}^{+}$ $\left(\mathrm{sNAD}^{+}\right), \mathrm{fPdAD}^{+}$and $\mathrm{ac}^{3} \mathrm{PdAD}^{+}$, respectively, as benzaldehyde has the same rotation barrier as pyridine3-aldehyde, 4.7 and $4.6 \mathrm{kcal} / \mathrm{mol}$, respectively [29]. The
TABLE I

Parameters for the 'out-of-plane' torsion angle of $\mathrm{NAD}^{+}$and its analogues

\begin{tabular}{llll}
\hline Compound & $\begin{array}{l}V_{n} / 2 \\
\left(\mathrm{kcal} \cdot \mathrm{mol}^{-1}\right)\end{array}$ & $\begin{array}{l}\gamma \\
(\mathrm{deg})\end{array}$ & $n$ \\
\hline $\mathrm{NAD}^{+}$ & 0.0 & 180 & 2 \\
sNAD $^{+}$ & 0.0 & 180 & 2 \\
$\mathrm{ac}^{3} \mathrm{PdAD}^{+}$ & 1.55 & 180 & 2 \\
$\mathrm{fPdAD}^{+}$ & 2.35 & 180 & 2 \\
\hline
\end{tabular}

rotation barrier was neglected for $\mathrm{NAD}^{+}$and $\mathrm{SNAD}^{+}$, since in benzamide a mean 'out-of-plane' rotation of $39^{\circ} \pm 2^{\circ}$ was observed [30], i.e., very close to the $45^{\circ}$ to be observed when there is no rotation barrier at all. * The torsion potentials introduced for the coenzymes are summarized in table I.

\section{Results and Discussion}

\section{Molecular mechanics calculations}

The geometries of the energy minimized $\mathrm{sNAD}^{+}$, $\mathrm{ac}^{3} \mathrm{PdAD}^{+}, \mathrm{fPdAD}^{+}$and $\mathrm{cn}^{3} \mathrm{PdAD}^{+}$, with respect to the energy minimized refined $\mathrm{NAD}^{+}$geometry, are given in Fig. 2. Since conformational differences (Table II) are restricted to the nicotinamide (or analogues) moiety, only these regions of the structures are drawn. Neither the zinc ion, nor the amino acids are depicted since they are invariant during all calculations.

As shown previously $[18,19]$, it appears that with molecular mechanics calculations there is a correct positioning of the $\mathrm{NAD}^{+}$pyridinium ring. From the present results, it is also clear that the calculated 'out-of-plane' torsion angle of $\mathrm{NAD}^{+}\left(34^{\circ}\right)$ fits well with the X-ray value $\left(30^{\circ}\right)$ reported by Eklund et al. [12] (see Table II). This further supports the correctness of our molecular mechanics approach.

Fig. 2 shows that in contrast to $\mathrm{SNAD}^{+}$the position of the pyridinium rings of $\mathrm{ac}^{3} \mathrm{PdAD}{ }^{+}, \mathrm{cn}^{3} \mathrm{PdAD}^{+}$and $\mathrm{fPdAD}^{+}$deviate from the $\mathrm{NAD}^{+}$pyridinium ring. It can also be observed that $\mathrm{fPdAD}^{+}$exhibits an opposite deviation as compared to $\mathrm{ac}^{3} \mathrm{PdAD}^{+}$and $\mathrm{cn}^{3} \mathrm{PdAD}^{+}$.

As far as the 'out-of-plane' torsion angle is concerned the thiocarbonyl group of the energy minimized $\mathrm{sNAD}^{+}$structure shows a larger torsion angle $\left(47^{\circ}\right)$ than the carbonyl group of $\mathrm{NAD}^{+}$(table II), while the torsion angles of $\mathrm{ac}^{3} \mathrm{PdAD}^{+}$and $\mathrm{PPdAD}^{+}$are strongly

\footnotetext{
* The difference in the introduced rotation barrier between the aldehyde and the ketone on the one hand and the amide on the other hand can be easily understood. The carboxamide group have their own resonance stabilization and therefore have no tendency to resonance interaction with the aromatic ring, whereas the aldehyde and ketone groups will do so. Their interactions will stabilize the flat conformation and increase the barrier.
} 

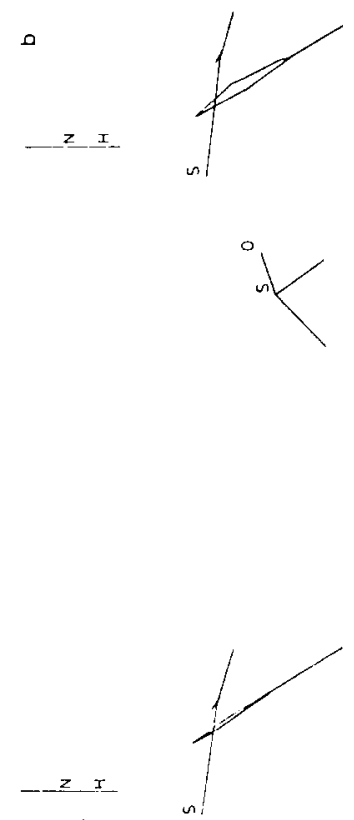

홍

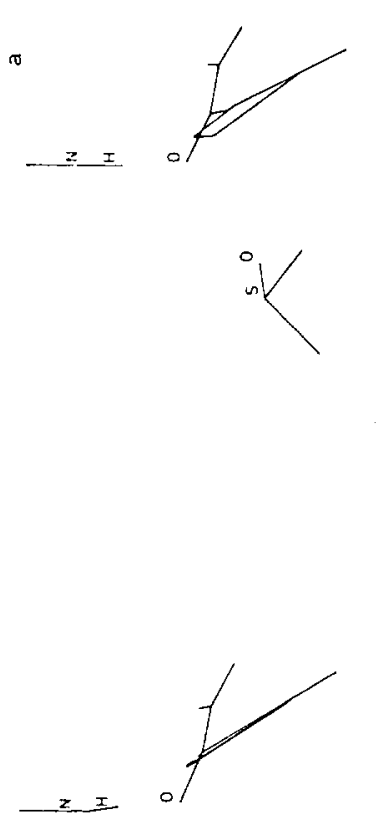

$\infty$

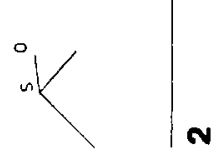

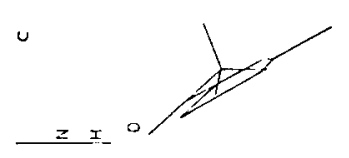
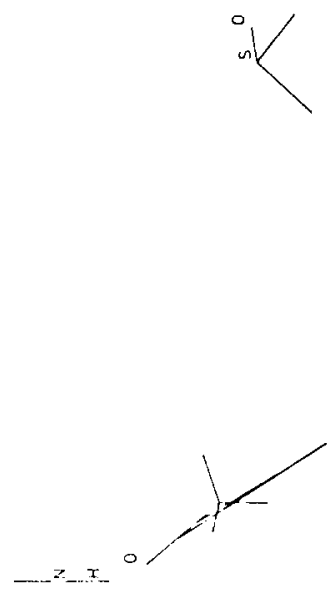

0
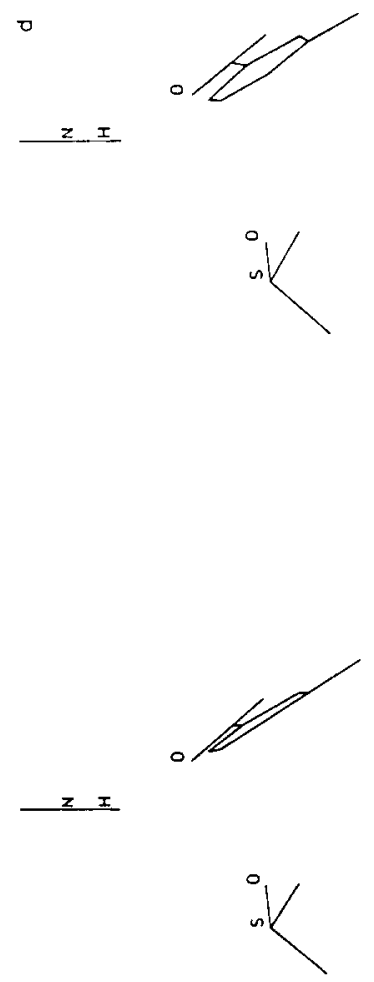

ข

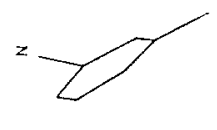

${ }^{\circ}$

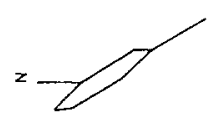

z.I

iv

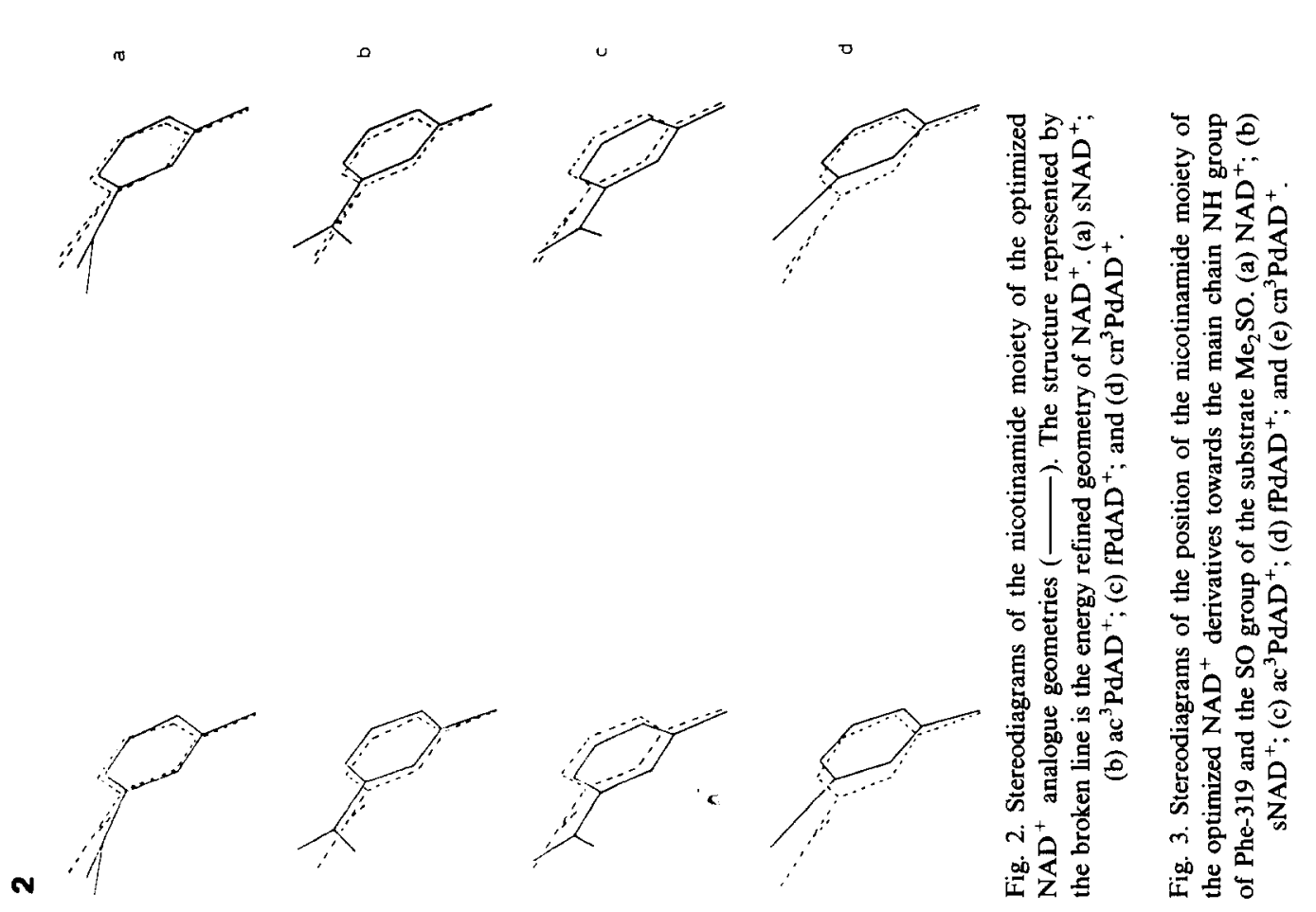


TABLE II

Conformational parameters of energy-refined $\mathrm{NAD}^{+}$and $\mathrm{NAD}^{+}$derivatives

Nomenclature of the coenzyme (analogue) torsion angles are the same as those used before [19].

\begin{tabular}{|c|c|c|c|c|c|c|c|c|c|c|c|}
\hline \multirow[t]{2}{*}{ Compound } & \multicolumn{10}{|c|}{ Torsion angle in degrees } & \multirow[t]{2}{*}{ out-of-plane $\phi$} \\
\hline & $\chi_{\mathrm{A}}$ & $\gamma_{\mathrm{A}}$ & $\beta_{\mathrm{A}}$ & $\alpha_{\mathrm{A}}$ & $\zeta_{\mathrm{A}}$ & $\zeta_{N}$ & $\alpha_{\mathrm{N}}$ & $\beta_{\mathrm{N}}$ & $\gamma_{N}$ & $\chi_{N}$ & \\
\hline$\overline{\text { NAD }}^{+}$ & 253 & 292 & 153 & 65 & 91 & 201 & 57 & 185 & 53 & 271 & 34 \\
\hline sNAD $^{+}$ & 253 & 292 & 154 & 64 & 90 & 202 & 56 & 187 & 55 & 270 & 47 \\
\hline $\mathrm{ac}^{3} \mathrm{PdAD}^{+}$ & 253 & 292 & 153 & 65 & 90 & 201 & 57 & 185 & 55 & 272 & 6.5 \\
\hline $\mathrm{fPdAD}^{+}$ & 253 & 292 & 153 & 65 & 90 & 203 & 56 & 191 & 50 & 274 & 9 \\
\hline $\mathrm{cn}^{3} \mathrm{PdAD}^{+}$ & 253 & 291 & 153 & 65 & 91 & 201 & 57 & 186 & 55 & 272 & - \\
\hline
\end{tabular}

diminished (6.5 and $9^{\circ}$, respectively). Obviously, $\mathrm{cn}^{3} \mathrm{PdAD}^{+}$exhibits no 'out-of-plane' rotation at all.

This is further illustrated in Fig. 3, which outlines the position of the nicotinamide (or analogue) moiety of the coenzyme with respect to the main chain $\mathrm{NH}$ group of Phe-319 and the substrate $\mathrm{Me}_{2} \mathrm{SO}$. Relevant data are given in Table III. Particularly the long distance between the carbonyl oxygen of $\mathrm{fPdAD}^{+}$and the sulfur atom of $\mathrm{Me}_{2} \mathrm{SO}$ is noteworthy, as will be discussed later.

\section{Kinetic studies}

Table IV summarizes our steady-state kinetic data obtained for $\mathrm{NAD}^{+}$and its analogues with isopropanol as substrate, in which the actual hydride transfer becomes rate limiting (see Introduction).

It appears that $\mathrm{sNAD}^{+}$and $\mathrm{ac}^{3} \mathrm{PdAD}^{+}$are more active than $\mathrm{NAD}^{+}, 4.1$ - and 2.3-times, respectively, whereas $\mathrm{fPdAD}^{+}$is less active (i.e. approx. $10 \%$ of $\mathrm{NAD}^{+}$). Finally, it is shown that $\mathrm{cn}^{3} \mathrm{PdAD}^{+}$is completely inactive.

In order to compare the kinetic data summarized in Table IV, the intrinsic reactivities of the compounds, $k_{\mathrm{SO}_{2-}}$, as measured by the addition of dithionite anion must also be taken into account (Table V).

\section{TABLE III}

Geometric and kinetic data of energy-refined $\mathrm{NAD}^{+}$and $\mathrm{NAD}^{+}$derivatives

\begin{tabular}{|c|c|c|c|c|c|}
\hline Compound & $\begin{array}{l}\phi \\
\text { (deg) }\end{array}$ & $\begin{array}{l}\text { N(Phe 319)- } \\
\text { O(C(O)R) } \\
(\mathrm{nm})\end{array}$ & $\begin{array}{l}\text { S(Me } \mathrm{Me}_{2} \mathrm{SO}- \\
\mathrm{O}(\mathrm{C}(\mathrm{O}) \mathrm{R}) \\
(\mathrm{nm})\end{array}$ & $\begin{array}{l}\mathrm{C} 4(\text { analog })- \\
\mathrm{C} 4\left(\mathrm{NAD}^{+}\right)^{a} \\
(\mathrm{~nm})\end{array}$ & $\begin{array}{l}k_{\text {cat }}{ }^{b} \\
\text { (rel) }\end{array}$ \\
\hline $\mathrm{NAD}^{+}$ & $34\left(30^{c}\right)$ & $0.29 \pm 0.02$ & $0.42 \pm 0.02$ & - & 1 \\
\hline $\mathrm{sNAD}^{+}$ & 47 & $0.34^{\mathrm{d}}$ & $0.39^{\bar{d}}$ & 0.02 & 4.12 \\
\hline $\mathrm{ac}^{3} \mathrm{PdAD}^{+}$ & 6.5 & 0.29 & 0.44 & 0.04 & 2.35 \\
\hline $\mathrm{fPdAD}^{+}$ & 9 & 0.29 & 0.51 & 0.06 & 0.12 \\
\hline $\mathrm{cn}^{3} \mathrm{PdAD}^{+}$ & - & - & - & 0.04 & $<0.01$ \\
\hline
\end{tabular}

a The $\mathrm{C} 4$ distance between $\mathrm{NAD}^{+}$and the analogue is a measure for the pyridinium shift.

b $k_{\text {cat }}$ values are from Table IV.

c Value obtained from X-ray analysis [12].

d Instead of oxygen, sNAD ${ }^{+}$has a sulfur atom bound in the side chain of the pyridinium ring.

\section{Discussion}

The reported results permit a correlation to je made between the geometric features of $\mathrm{NAD}^{+}$and its analogues in the active site and the measured kinetic data with isopropanol, taking into account the intrinsic reactivities.

\section{TABLE IV}

Kinetic parameters derived from Eqn. I for $L A D H$ with $N A D^{+}$, $a c^{3} P d A D^{+}, s N A D^{+}, f P d A D^{+}, c n^{3} P d A D^{+}$and the substrate isopropanol

\begin{tabular}{lcll}
\hline Compound & \multicolumn{3}{l}{ Isopropanol } \\
\cline { 2 - 4 } & $\begin{array}{l}K_{\mathrm{a}} \\
(\mu \mathrm{M})\end{array}$ & $\begin{array}{l}K_{\mathrm{b}} \\
(\mathrm{mM})\end{array}$ & $\begin{array}{l}k_{\text {cat }} \\
(\%)\end{array}$ \\
\hline NAD $^{+}$ & 37 & 1.3 & $100^{\mathrm{a}}$ \\
sNAD $^{+}$ & 249 & 6.0 & $412^{3}$ \\
$\mathrm{ac}^{3} \mathrm{PdAD}^{+}$ & 309 & 3.5 & 235 \\
PPdAD $^{+}$ & 261 & 0.5 & 12 \\
cn PdAD $^{3}$ & - & - & $<1^{\mathrm{b}}$ \\
\hline
\end{tabular}

${ }^{a}$ Equals $0.85 \mathrm{~s}^{-1}$, in accordance with literature data [13].

${ }^{b}$ See Refs. 31 and 32.

\section{TABLE V}

Kinetic data of $\mathrm{NAD}^{+}$and derivatives in the reaction with dithionite and in the enzymatic reduction with isopropanol

\begin{tabular}{|c|c|c|c|}
\hline Compound & $\begin{array}{l}k_{\text {cat }}(\text { isoprop) } \\
\text { (rel) }\end{array}$ & $\begin{array}{l}k_{\mathrm{SO}_{2}^{-}} \\
\text {(rel) }\end{array}$ & $\begin{array}{l}\phi \\
(\mathrm{deg})\end{array}$ \\
\hline $\mathrm{NAD}^{+}$ & 1.0 & $1^{a}$ & 34 \\
\hline sNAD $^{+}$ & 4.12 & $3^{a}$ & 47 \\
\hline $\mathrm{ac}^{3} \mathrm{PdAD}^{+}$ & 2.35 & $22^{a}$ & 6.5 \\
\hline $\mathrm{fPdAD}^{+}$ & 0.12 & $16^{\mathrm{b}}$ & 9 \\
\hline $\mathrm{cn}^{3} \mathrm{PdAD}{ }^{+}$ & $<0.01$ & $32^{b}$ & - \\
\hline \multicolumn{4}{|c|}{$\begin{array}{l}\mathrm{NAD}^{+}, 47 \mathrm{M}^{-1} \cdot \mathrm{s}^{-1} ; \mathrm{ac}^{3} \mathrm{PdAD}^{+}, 1050 \mathrm{M}^{-1} \cdot \mathrm{s}^{-1} \text {; and } \mathrm{sNAD}^{+}, 150 \\
\mathrm{M}^{-1} \cdot \mathrm{s}^{-1} \cdot(\text { see Ref. } 33 \text { ). } \\
\text { The intrinsic reactivity is calculated from the known linear relation- } \\
\text { ship between the } \log k_{\mathrm{SO}_{2}^{-}} \text {(rate constant) for the dithionite reduc- } \\
\text { tion and the redox potential, showing a higher rate of dithionite } \\
\text { reduction with increasing potential [33]. With a redox potential of } \\
-262 \mathrm{mV} \text { [34], for fPdAD }{ }^{+} \text {an intrinsic reactivity of about } 730 \\
\mathrm{M}^{-1} \cdot \mathrm{s}^{-1} \text { has been obtained. Similarly a redox potential of }-240 \\
\mathrm{mV}[31] \text { for } \mathrm{cn}^{3} \mathrm{PdAD}^{+} \text {results in a } \mathrm{k}_{\mathrm{SO}_{2}^{-}} \text {of } 1513 \mathrm{M}^{-1} \cdot \mathrm{s}^{-1} \\
\text { [33]. }\end{array}$} \\
\hline
\end{tabular}



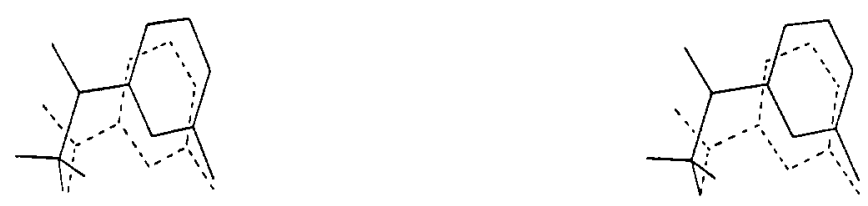

Fig. 4. Stereodiagram showing the pyridinium positions of $\operatorname{ac}^{3} \operatorname{PdAD}^{+}(\square)$ and $\operatorname{fPdAD}^{+}(-\ldots \ldots)$.

The high $k_{\text {cat }}$ value of $\mathrm{sNAD}^{+}$compared to $\mathrm{NAD}^{+}$, exhibiting identical positions of their pyridinium rings, can easily be explained by the large value for the 'out-of-plane' orientation and the high intrinsic reactivity (see Table V).

Although the intrinsic reactivity of $\mathrm{ac}^{3} \mathrm{PdAD}^{+}$is higher than that of $\mathrm{SNAD}^{+}$(Table V) its enzymatic activity is lower. Since the position of the pyridinium ring of $\mathrm{ac}^{3} \mathrm{PdAD}^{+}$only slightly differs from $\mathrm{NAD}^{+}$, this observation must be mainly explained by the low 'out-of-plane' torsion angle of the acetyl group.

The intrinsic reactivity of $\mathrm{PPdAD}^{+}$is almost equal to that of $\mathrm{ac}^{3} \mathrm{PdAD}^{+}$, as are their 'out-of-plane' torsion angles. One should therefore expect about equal activities in the enzyme. Actually the activity of $\mathrm{fPdAD}^{+}$is lower by an order of magnitude (Table IV). This might be due to the position of its head group not being precisely maintained, as a consequence of the lack of the methyl group (or the $\mathrm{NH}_{2}$ group) in the side chain; the difference between $\mathrm{C4}\left(\mathrm{ac}^{3} \mathrm{PdAD}^{+}\right)$and $\mathrm{C} 4$ $\left(\mathrm{PdAD}^{+}\right)$is $0.09 \mathrm{~nm}$. This is also indicated by the long distance between the carbonyl oxygen and the sulfur atom of $\mathrm{Me}_{2} \mathrm{SO}$, corresponding to the substrate carbon atom that donates the hydride ion (Fig. 3 and Table III).

Most striking are the data obtained with the cyano analogue. According to our calculations the position of the pyridinium ring of $\mathrm{cn}^{3} \mathrm{PdAD}^{+}$virtually coincides with that of the pyridinium ring of $\mathrm{ac}^{3} \mathrm{PdAD}^{+}$. However, the cyano analogue is practically inactive in the dehydrogenase, notwithstanding its high intrinsic reactivity. The conclusion can be drawn that this is due to the absence of any 'out-of-plane' rotation of the $\mathrm{CN}$ group (vide infra).

The enhancing effect of the carboxamide side chain is ascribed to the $\delta^{-}$charge of the carbonyl oxygen ( -0.28 e.u.), stabilizing the positive charge on $\mathrm{Cl}$ of the substrate in the transition state [15]. In the case of the cyano analogue the cyano group occupies an unfavourable position (Fig. 3), the distance between the $\delta^{-}$charge of the nitrogen atom and the sulphur atom of the substrate $(0.54 \mathrm{~nm})$ being larger than the distance between the $\delta^{+}$charge of the carbon atom and the sulphur atom $(0.48 \mathrm{~nm})$. The cyano group may therefore even retard the hydride transfer.

In conclusion, we have demonstrated that the kinetic data obtained with the $\mathrm{NAD}^{+}$analogues can be related to their geometry in the alcohol dehydrogenase. Particu- larly the magnitude of the 'out-of-plane' rotation of the side chain of the pyridinium ring is decisive.

\section{Acknowledgements}

Use of the services and facilities of the Dutch CAOS/CAMM Center under grant numbers SON-1120-700 and STW-NCH-44.0703, is gratefully acknowledged.

\section{References}

1 Colowick, S.P., Van Eijs, J. and Park, J.M. (1966) Comp. Biochem. $14,38-46$.

2 Biellmann, J.-F. (1983) in 34 Colloquium-Mosbach, Biological Oxidations, pp. 55-61, Springer-Verlag, Berlin.

3 Biellmann, J.-F., Hirth, C.G., Jung, M.J., Rosenheimer, N. and Wrixon, A.D. (1974) Eur. J. Biochem. 41, 517-524.

4 Boyer, P.D., Lardy, H. and Myrbäck, K. (1963) The Enzymes 2nd Edn., Vol. 7, 42.

5 Samama, J.-P., Marchal-Rosenheimer, N., Biellmann, J.-F. and Rossmann, M.G. (1981) Eur. J. Biochem. 120, 563-569.

6 Shore, J.D. and Theorell, H. (1967) Eur. J. Biochem. 2, 32-36.

7 Shore, J.D. and Brooks, R.L. (1971) Arch. Biochem. Biophys. 147, 825-827.

8 Kaplan, N.O., Ciotti, M.M. and Stolzenbach, F.E. (1956) J. Biol. Chem. 221, 833-844.

9 Anderson, B.M., Anderson, C.D., Lee, J.K. and Stein, A.M. (1963) Biochemistry 2, 1017-1022.

10 Baici, A., Luisi, P.L. and Attanasi, O. (1975/76) J. Mol. Catal. 1, 223-244.

11 Anderson, B.M. and Kaplan, N.O. (1959) J. Biol. Chem. 234, 1226-1232.

12 Eklund, H., Samama, J.P. and Jones, T.A. (1984) Biochemistry 23, 5982-5996.

13 Dalziel, K. and Dickinson, F.M. (1966) Biochem. J. 100, 34-46.

14 Donkersloot, M.C.A. and Buck, H.M. (1981) J. Am. Chem. Soc. 103, 6554-6558.

15 De Kok, P.M.T., Donkersloot, M.C.A., Van Lier, P.M., Meulendijks, G.H.W.M., Bastiaansen, L.A.M., Van Hooff, H.J.G., Kanters, J.A. and Buck, H.M. (1986) Tetrahedron 42, 941-959.

16 De Kok, P.M.T., Bastiaansen, L.A.M., Van Lier, P.M., Vekemans, J.A.J.M. and Buck, H.M. (1989) J. Org. Chem. 54, 1313-1320.

17 Skarzynski, T., Moody, P.C.E. and Wonacott, A.J. (1987) J. Mol. Biol. 193, 171-187.

18 De Kok, P.M.T., Beijer, N.A., Buck, H.M., Sluyterman, L.A.AE. and Meijer, E.M. (1988) Recl. Trav. Chim. Pays-Bas 107, 355-361.

19 De Kok, P.M.T., Beijer, N.A., Buck, H.M., Sluyterman, L.A.AE. and Meijer, E.M. (1988) Eur. J. Biochem. 175, 581-585.

20 Wallén, L. and Branlant, G. (1983) Eur. J. Biochem. 137, 67-73.

21 Vorontsov, E.A., Kalacheva, N.I., Lifshits, N.L., Mal'tsev, N.I., Yanina, M.M. and Gurevich, V.M. (1979) Biokhimiya 44, 324-331.

22 Fisher, T.L., Vercellotti, S.V. and Anderson, B.M. (1973) J. Biol. Chem. 248, 4293-4299. 
23 Sund, H. and Theorell, H. (1962) Enzymes 7, 25-83.

24 Weiner, P.K. and Kollman, P.A. (1981) J. Comp. Chem. 2, 287303.

25 Weiner, S.J., Kollman, P.A., Case, D.A., Singh, U.C., Ghio, C., Alagona, G., Profeta, S. and Weiner, P.K. (1984) J. Am. Chem. Soc. 106, 765-784.

26 Weiner, S.J., Kollman, P.A., Nguyen, D.T. and Case, D.A. (1986) J. Comp. Chem. 7, 230-252.

27 Cummins, P.L. and Gready, J.E. (1989) J. Mol. Struct. (Theochem) $183,161-174$.

28 Kakar, R.K., Rinehart, E.A., Quade, C.R. and Kojima, T. (1970) J. Chem. Phys. 52, 3803-3813.

29 Miller, F.A., Fateley, W.G. and Witkowski, R.E. (1967) Spectrochim. Acta A 23, 891-908.
30 Pierens, R.K. and Williams, A.J. (1980) J. Chem. Soc. Perkins Trans. II, 235-242.

31 Woenckhaus, C. and Jeck, R. (1987) in Coenzymes and Cofactors, Pyridine Nucleotide Coenzymes (Dolphin, D., Avramovic, O. and Poulson, R., eds.), Vol. 2A, pp. 449-568, John Wiley \& Sons, New York.

32 Kazlauskas, R.J. (1988) J. Org. Chem. 53, 4633-4635.

33 Blankenhorn, G. and Moore, E.G. (1980) J. Am. Chem. Soc. 102, 1092-1098.

34 Scharschmidt, M., Fisher, M.A. and Cleland, W.W. (1984) Biochemistry $23,5471-5478$. 